DOI: $10.19195 / 0137-1134.114 .39$

\title{
BOŻENA POPOWSKA
}

Uniwersytet im. Adama Mickiewicza w Poznaniu bozenapopowska@op.pl

\section{NOWE PROCEDURY PUBLICZNEGO PRAWA GOSPODARCZEGO. PROBLEM GWARANCJI PROCESOWYCH DLA PODMIOTÓW DZIAŁALNOŚCI GOSPODARCZEJ}

\begin{abstract}
Abstrakt: Podstawowym przedmiotem badań niniejszego artykułu są nowe procedury unormowane przepisami publicznego prawa gospodarczego. Głównym celem opracowania jest określenie ich charakteru prawnego, z odniesieniem do ogólnego postępowania administracyjnego. Stosowane w sferze gospodarki procedury normujące relacje między administracją publiczną a przedsiębiorcami są bowiem bardzo różne. Część z nich opiera się na modelu postępowania jurysdykcyjnego, unormowanym przepisami kodeksu postępowania administracyjnego, aczkolwiek należy wyróżnić także postępowania, których podstawową funkcją jest realizacja określonych interesów (celów) publicznych — postępowania te nie stanowią jednolitej kategorii, a relacje między podmiotem administracji publicznej a przedsiębiorcą są w nich normowane w rozmaity sposób.
\end{abstract}

Słowa kluczowe: publiczne prawo gospodarcze, procedury, gwarancje procesowe

Możliwość zamieszczenia w księdze pamiątkowej dla Prof. Leona Kieresa swojego artykułu to dla mnie zaszczyt. Jubileusz Pana Profesora stanowi bowiem dla mnie szczególną okazję wypowiedzenia się odnośnie do zagadnień, nad którymi wiele razy wspólnie obradowaliśmy podczas cyklicznie organizowanych konferencji Katedr Publicznego Prawa Gospodarczego Uniwersytetu Wrocławskiego i Uniwersytetu im. Adama Mickiewicza w Poznaniu. Większość spotkań poświęcona była tematyce funkcjonowania podmiotów administracji publicznej w sferze gospodarki ${ }^{1}$. Przedmiotem jednej z ostatnich konferencji były zagadnienia procesowoprawne unormowane publicznym prawem gospodarczym; jej pokłosiem jest książka zatytułowana Swoistość procedur publicznego prawa go-

1 Zob. zwłaszcza Funkcje współczesnej administracji gospodarczej, red. B. Popowska, Poznań 2006; Środki prawne publicznego prawa gospodarczego, red. L. Kieres, Wrocław 2007; Instrumenty i formy prawne działania administracji gospodarczej, red. B. Popowska, K. Kokocińska, Poznań 2009. 
spodarczego ${ }^{2}$. Wskazuje się w niej na regulację specjalnych procedur służących załatwianiu spraw normowanych publicznym prawem gospodarczym. Wnioski wyprowadzane w tym zakresie podbudowały tezę o odrębności proceduralnego publicznego prawa gospodarczego ${ }^{3}$. Nawiązując do jednego z licznych wątków zainteresowań naukowych Prof. L. Kieresa ${ }^{4}$, zdecydowałam się zaproponować kontynuację dyskusji nad „swoistością” procedur publicznego prawa gospodarczego, wyrażając tym samym uznanie dla dorobku Pana Profesora w tym zakresie.

Szanowny Panie Profesorze, Drogi Leonie, proszę przyjąć ten artykuł jako wyraz szacunku oraz uznania dla zasług Pana Profesora na wielu płaszczyznach życia społecznego i zawodowego, w tym jako naukowca, organizatora oraz popularyzatora nauki. Dziękuję za możliwość współpracy, gratuluję jubileuszu oraz życzę zdrowia, pomyślności i szczęścia.

\section{CEL I ZAKRES ARTYKUŁU}

Rozwinięcie tezy o odrębności proceduralnego publicznego prawa gospodarczego wymaga przypomnienia, że publiczne prawo gospodarcze normuje różne postępowania dotyczące relacji między podmiotami administracji publicznej a przedsiębiorcami. Dlatego też w jednym z opracowań opublikowanych pod redakcją L. Kieresa podjęłam się próby usystematyzowania procedur unormowanych publicznym prawem gospodarczym ${ }^{5}$, odnosząc je do modelu postępowania jurysdykcyjnego w kodeksie postępowania administracyjnego ${ }^{6}$. Rozwój omawianej tu gałęzi prawa: regulacja nowych procedur, modyfikowanie istniejących oraz rozwój doktryny prawa procesowego gospodarczego, a także rozważania systemowe dotyczące prawa procesowego administracyjnego ${ }^{7}$ zachęcają do ponownego przeglądu

2 Swoistość procedur publicznego prawa gospodarczego, red. B. Popowska, Poznań 2013.

3 Zob. C. Kosikowski, Publiczne prawo gospodarcze Polski i Unii Europejskiej, Warszawa 2007, s. 48; K. Kiczka, Prawo administracyjne gospodarcze w systemie prawa administracyjnego, [w:] Koncepcja systemu prawa administracyjnego, red. J. Zimmermann, Warszawa 2007, s. 74; K. Kiczka, O niektórych aspektach procedur w publicznym prawie gospodarczym, [w:] Swoistość procedur..., s. 55.

${ }^{4}$ Zob. też L. Kieres, Sprawna administracja w orzecznictwie Trybunatu Konstytucyjnego, [w:] Administracja publiczna pod rzadami prawa. Księga pamiątkowa z okazji 70-lecia urodzin prof. zw. dra hab. Adama Błasia, red. J. Korczak, Wrocław 2016, s. 193-216.

5 B. Popowska, Publiczne prawo gospodarczej w płaszczyźnie proceduralnej, [w:] Nowe problemy badawcze w teorii publicznego prawa gospodarczego ( $z$ uwzględnieniem samorzadu terytorialnego), red. L. Kieres, Wrocław 2010, s. 209-242.

${ }^{6}$ Ustawa z dnia 14 czerwca $1960 \mathrm{r}$. - Kodeks postępowania administracyjnego (tekst jedn. Dz.U. z 2017 r. poz. 1257; dalej: k.p.a.).

7 Na potrzeby tej pracy uwzględniłam zwłaszcza trzy opracowania z publikacji System Prawa Administracyjnego (t. 9. Prawo procesowe administracyjne, red. R. Hauser, Z. Niewiadomski, Warszawa 2014): B. Adamiak, Koncepcja postepowania administracyjnego ([w:] System Prawa Admi- 
procedur publicznego prawa gospodarczego i próby ich uporządkowania. Jest to tym bardziej zasadne, że powszechnie zauważa się, iż procedury publicznego prawa gospodarczego coraz bardziej odchodzą od ogólnego postępowania administracyjnego i korzystają z różnych instytucji (konstrukcji) procesowych w relacjach podmiot administracji publicznej-przedsiębiorca ${ }^{8}$. Z tym zaś kierunkiem zmian wiąże się istotna kwestia gwarancji procesowych ochrony praw przedsiębiorcy $\mathrm{w}$ toku postępowania prowadzonego przez podmiot administracji publicznej.

Mając na uwadze ograniczone ramy wypowiedzi, zdecydowałam, że podstawowym przedmiotem niniejszych badań będą nowe procedury unormowane przepisami publicznego prawa gospodarczego, a głównym celem — określenie ich charakteru prawnego, z odniesieniem do ogólnego postępowania administracyjnego. Pozostający w związku z tak zaproponowanymi rozważaniami problem gwarancji procesowych dla podmiotów działalności gospodarczej zostanie jedynie wstępnie zarysowany poprzez wskazanie znaczenia zasad ogólnych k.p.a. oraz zasad ogólnych normowanych przepisami publicznego prawa gospodarczego. $\mathrm{O}$ wadze problematyki zasad ogólnych świadczy niedawna nowelizacja k.p.a., obejmująca również takie zasady ${ }^{9}$, a także projekt ustawy Prawo przedsiębiorców ${ }^{10}$, normującej między innymi ogólne zasady postępowania w relacjach organów władzy publicznej z przedsiębiorcami. Projekt tej ustawy ma zastąpić ustawę z dnia 2 lipca 2004 roku o swobodzie działalności gospodarczej ${ }^{11}$, która stanowi podstawowy akt prawny w zakresie prawa działalności gospodarczej.

\section{ZAGADNIENIA WSTĘPNE. POSTĘPOWANIA DOTYCZĄCE POZYCJI PRAWNEJ PRZEDSIĘBIORCY I POSTĘPOWANIA DOTYCZĄCE GOSPODARKI}

Rozważania porządkujące postępowania normowane przepisami publicznego prawa gospodarczego należy zacząć od wskazania przyczyn tej różnorodności, to jest przedmiotu i zakresu normowania tego prawa. Ogólnie ujmując, przedmiotem regulacji publicznego prawa gospodarczego są relacje między administracją

nistracyjnego, t. 9, s. 1-8); J. Borkowski, A. Krawczyk, Prawo procesowe ogólne, prawo procesowe szczególe ([w:] System Prawa Administracyjnego, t. 9, s. 89-99); oraz iidem, Aspekt przedmiotowy regulacji prawa procesowego administracyjnego ([w:] System Prawa Administracyjnego, t. 9, zwł. s. $140-146)$.

${ }^{8}$ Zob. C. Kosikowski, op. cit., s. 48; K. Kiczka, Prawo administracyjne gospodarcze..., s. 74; idem, O niektórych aspektach procedur..., s. 55.

9 Ustawa z dnia 7 kwietnia 2017 r. o zmianie ustawy - Kodeks postępowania administracyjnego oraz niektórych innych ustaw (Dz.U. z 2017 r. poz. 935) weszła w życie 1 czerwca 2017 r.

10 Projekt wpłynął do Sejmu 21 listopada 2017 r., a 8 grudnia 2017 r. odbyło się pierwsze czytanie.

11 Tekst jedn. Dz.U. z 2015 r. poz. 584 ze zm. (dalej: USDG). 
a gospodarką. Przepisy tej gałęzi prawa normują zadania (funkcje) państwa wobec gospodarki ${ }^{12}$ oraz prawa i obowiązki przedsiębiorców, ustalane $\mathrm{z}$ względu na funkcje państwa ${ }^{13}$. Jak $z$ tego wynika, gospodarki nie można utożsamiać wyłącznie z sytuacją przedsiębiorcy. Zgodzić się zatem należy z poglądem, że

segment gospodarka [...] nie może być badany jedynie pod kątem kształtowania pozycji prawnej przedsiębiorcy, a w szczególności ochrony jego praw i interesów, lecz także z punktu widzenia gwarancji sprawności mechanizmów gospodarczych (np. konkurencji) ${ }^{14}$.

Wskazać można także inne cele działań administracji w sferze gospodarki, takie jak ochrona mienia państwowego lub inwestycji (obiektów) mających znaczenie dla gospodarki, bezpieczeństwa obywateli, porządku publicznego itp. Odrębną kategorię tworzą procedury zawierania przez administrację umów $\mathrm{z}$ przedsiębiorcami ${ }^{15}$.

Regulacja publicznego prawa gospodarczego w kwestiach materialnoprawnych znajduje swoje odzwierciedlenie w przepisach dotyczących relacji procesowoprawnych w normowanej przestrzeni ${ }^{16}$. Poza procedurami właściwymi realizacji stosunków administracyjnoprawnych, to jest między administracją a obywatelem lub przedsiębiorcą (podstawowy model normuje kodeks postępowania administracyjnego) zastosowanie znajdują procedury, które tworzy się specjalnie na

12 Uogólniając, można powiedzieć, że zadania administracji w sferze gospodarki skupiają się na organizacji (regulacji) rozwoju życia gospodarczego i wspieraniu przedsiębiorczości prywatnej, a także na wykorzystywaniu własności publicznej w gospodarce. Zob. H. Izdebski, M. Kulesza, Administracja publiczna, zagadnienia ogólne, Warszawa 2004, s. 104, 112-124.

13 T. Rabska, Jakie prawo gospodarcze? - próba odpowiedzi, „Ruch Prawniczy, Ekonomiczny i Socjologiczny” (dalej: RPEiS) 1993, nr 1, s. 21. Zob. też C. Kosikowski, Polskie publiczne prawo gospodarcze, Warszawa 2000, s. 24. Na temat funkcji państwa zob. B. Popowska, Klasyfikacja funkcji administracji w nauce publicznego prawa gospodarczego, [w:] Funkcje wspótczesnej administracji gospodarczej, red. B. Popowska, Poznań 2006, s. 61-86.

14 K. Strzyczkowski, Uwagi o zadaniach nauki o prawnych formach działania administracji gospodarczej, [w:] Instrumenty i formy prawne..., s. 60.

15 To zagadnienie pozostaje poza niniejszymi rozważaniami z uwagi na specyfikę tych procedur, co znajduje swoje odzwierciedlenie między innymi w odrębnym systemie ich kontroli. Por. w kwestii procedury wyboru partnera prywatnego umowy koncesji stanowisko B. Adamiak, [w:] Koncepcja postępowania administracyjnego, s. 6. Należy dodać, że problematyka ta jest szeroko omawiana w doktrynie, także przez autorkę tego opracowania; zob. np. B. Popowska, Kwalifikacja prawna umowy koncesji; instrument ,mieszany” czy typowy dla realizacji zadań gospodarczych przez administrację publiczna??, [w:] Prawne instrumenty oddziaływania na gospodarkę, red. A. Powałowski, Warszawa 2016; eadem, Partnerstwo publiczno-prywatne w świetle koncepcji ,ciagu działań prawnych" i jej wptyw na ocenę umowy o PPP, [w:] Środki prawne..., s. 153.

16 Zob. Z. Kmieciak, Postepowanie w sprawach ochrony konkurencji a koncepcja procedury hybrydowej, „Państwo i Prawo” (dalej: PiP) 2002, nr 8, s. 31 n. Należy podkreślić, że w ramach publicznego prawa gospodarczego nie są odrębnie skodyfikowane reguły postępowania organów administracji w sferze gospodarki. W większości źródeł tego prawa — ustaw i aktów wykonawczych — normy proceduralne występują obok norm materialnych i ustrojowych. 
użytek „obsługi” danego rodzaju stosunków prawnych, na przykład zwalczania praktyk monopolistycznych, prowadzenia kontroli czy nadzoru nad czynnościami prawnymi państwowych osób prawnych ${ }^{17}$. Tak więc to prawodawca decyduje o prawnym kształcie postępowania w różnych sferach działania, a w konsekwencji — o różnych typach relacji administracji z przedsiębiorcami. Decyduje również o tym, w jakich sprawach i w jakim zakresie zastosowanie znajdują przepisy k.p.a., a także czy i w jakim zakresie występują szczególne regulacje publicznego prawa gospodarczego, w tym zasady ogólne.

\section{POSTĘPOWANIA DOTYCZĄCE PRAW I OBOWIĄZKÓW PRZEDSIĘBIORCÓW. STOSOWANIE PROCEDUR OPARTYCH NA MODELU POSTĘPOWANIA UNORMOWANEGO W K.P.A.}

Znaczące miejsce $\mathrm{w}$ publicznym prawie gospodarczym zajmują procedury, które mieszczą się w ramach koncepcji postępowania administracyjnego w wąskim znaczeniu, to jest postępowania, którego przedmiotem jest autorytatywna konkretyzacja normy materialnego prawa dotyczącej uprawnienia lub obowiązku obywatela (tu: przedsiębiorcy) w formie decyzji administracyjnej ${ }^{18}$. Zasady takiego postępowania, instytucje i tok postępowania unormowane są w k.p.a. (postępowanie jurysdykcyjne).

Charakterystyczne dla publicznego prawa gospodarczego jest wykorzystanie wzorca postępowania unormowanego w k.p.a., z odwołaniem od decyzji i kontrolą sądowoadministracyjną, wraz ze swoistymi rozwiązaniami procesowymi. Uzupełniają one regulacje k.p.a. przepisami proceduralnymi właściwymi danej sferze gospodarki, na przykład w Prawie bankowym ${ }^{19}$, albo tworzą — poza trybem „podstawowym” - także inne tryby z wykorzystaniem formy prawnej decyzji, na przykład w sprawach koncesjonowania działalności gospodarczej ${ }^{20}$. Owe odrębności znajdują wyraz także w szczególnych zasadach związanych z określonym modelem postępowania ${ }^{21}$, oprócz zasad ogólnych unormowanych w k.p.a.

17 Por. C. Kosikowski, Polskie publiczne prawo gospodarcze, s. 52.

18 Por. B. Adamiak, op. cit., zwł. s. $3,8$.

19 Na przykład w myśl art. 36 ustawy z dnia 29 sierpnia 1997 r. — Prawo bankowe (tekst jedn. Dz.U. z 2017 r. poz. 1876 ze zm.) normuje tryb wydania dwóch zezwoleń — na utworzenie banku, art. 34, i na podjęcie działalności bankowej - musi być poprzedzone postępowaniem administracyjnym w sprawie uzyskania zezwolenia na utworzenie banku — art. 36.

${ }^{20}$ USDG normuje, poza trybem „zwykłym”, dwa odrębne tryby uzyskania koncesji: poprzedzone wydaniem promesy (art. 60) i przetargowe (art. 51, 53, 54 i 56).

$21 \mathrm{Na}$ przykład w postępowaniu przetargowym w sprawach udzielenia koncesji o wyborze koncesjonariusza - spośród przedsiębiorców spełniających określone warunki, decyduje najwyższa opłata za koncesję (art. 54 USDG). 
Odrębny typ postępowania administracyjnego stanowią procedury określane jako „hybrydowe”, to jest procedury złożone, zawierające oprócz elementów właściwych postępowaniu administracyjnemu również składowe właściwe odmiennym typom postępowań ${ }^{22}$. Szczegółowe unormowanie takiej procedury zawiera ustawa z dnia 16 lutego 2007 roku o ochronie konkurencji i konsumentów ${ }^{23}$, przewidująca między innymi szczególną instytucję odwołania od decyzji w formie pozwu (a także kontrolę odrębnego sądu cywilnoprawnego, to jest Sądu Ochrony Konkurencji i Konsumentów ${ }^{24}$. To postępowanie i podobne, normowane przepisami ustaw: Prawo energetyczne ${ }^{25}$, Prawo telekomunikacyjne ${ }^{26}$ i Prawo transportu kolejowe$\mathrm{go}^{27}$, mimo istotnych modyfikacji procedury unormowanej w k.p.a. zachowuje charakter postępowania ogólnego ${ }^{28}$. Warto jednak zauważyć, że szeroki zakres odrębnych regulacji w procedurach hybrydowych marginalizuje stosowanie w ich ramach instytucji k.p.a., w tym zasad ogólnych. Na płaszczyźnie materialnoprawnej należy natomiast podkreślić, że w tych postępowaniach działania właściwych organów motywowane są przede wszystkim interesem publicznymi, a rozstrzygnięcia organu stanowią autorytatywną konkretyzację określonych nakazów bądź zakazów unormowanych przepisami publicznego prawa gospodarczego. Procedury te, $\mathrm{z}$ uwagi na bogatą literaturę na ten temat, $\mathrm{w}$ tym opracowaniu nie będę omawiane.

22 Zob. Z. Kmieciak, op. cit., s. 31, 46-47; J. Borkowski, A. Krawczyk, Przedmiot regulacji prawa procesowego administracyjnego. Rodzaje spraw i ich charakter prawny: sprawa indywidualna bez ograniczenia przedmiotowego, sprawa podatkowa jako rodzaj sprawy administracyjnej, [w:] System Prawa Administracyjnego, t. 9, zwł. s. 145-146.

23 Tekst jedn. Dz.U. z 2017 r. poz. 229 ze zm. Przepisy tej ustawy normują całe postępowanie przed organem - Prezesem Urzędu Ochrony Konkurencji i Konsumentów, prowadzące do wydania decyzji, w ramach którego występują także instytucje procedury cywilnoprawnej (art. 60 i 83) oraz procedury karnej (art. 105 ust. q).

24 Postępowanie sądowe prowadzone jest w trybie przepisów o postępowaniu cywilnym (rozdz. 2, dział IVa ustawy z dnia 17 listopada 1964 r. - Kodeks postępowania cywilnego, tekst jedn. Dz.U. z 2016 r. poz. 1822 ze zm.). Podobny model postępowania administracyjnego, a także ochrony sądowej, jak w wypadku publicznoprawnych spraw ochrony konkurencji (antymonopolowych) zastosowano w niektórych sprawach z zakresu regulacji energetyki, regulacji telekomunikacji oraz regulacji transportu kolejowego.

25 Ustawa z dnia 10 kwietnia 1997 r. — Prawo energetyczne (tekst. jedn. Dz.U. z 2017 r. poz. $220 \mathrm{ze} z \mathrm{zm}$.).

${ }^{26}$ Ustawa z dnia 16 lipca 2004 r. — Prawo telekomunikacyjne (tekst jedn. Dz.U. z 2017 r. poz. 1907 ze zm.).

27 Ustawa z dnia 28 marca 2003 r. o transporcie kolejowym (tekst jedn. Dz.U. z 2017 r. poz. 2117 ze zm.).

28 Zob. J. Borkowski, A. Krawczyk, Przedmiot regulacji prawa..., s. 145-146. 


\section{POSTĘPOWANIA NIEZWIĄZANE Z AUTORYTATYWNĄ} KONKRETYZACJĄ NORMY PRAWA MATERIALNEGO W ZAKRESIE UPRAWNIENIA LUB OBOWIĄZKU PRZEDSIĘBIORCY.

\section{ZAGADNIENIA WSTĘPNE}

W ramach postępowań prowadzonych przez administrację w sferze gospodarki można wyróżnić takie, których podstawową funkcją nie jest kształtowanie pozycji prawnej przedsiębiorcy ${ }^{29}$, a przesłanką wchodzenia w relacje zewnętrzne z przedsiębiorcami jest realizacja określonych celów (interesów) gospodarki, takich jak ochrona (przed tak zwanym wrogim przejęciem ${ }^{30}$ ) niektórych przedsiębiorców ze względu na znaczenie dla gospodarki, zachowanie integralności (ochrona) infrastruktury krytycznej czy ochrona mienia państwowego. Należy podkreślić, że realizacja tych celów następuje poprzez władczą ingerencję właściwych organów w zakres podejmowanych przez samodzielne podmioty gospodarcze czynności prywatnoprawnych objętych swobodą umów.

W tym szerokim spektrum występują różne procedury. Aby je, skrótowo ze względu na objętość artykułu, przedstawić, można sięgnąć do przepisów dwóch ustaw, które weszły w życie w 2016 roku — chodzi o ustawę z dnia 24 lipca 2015 roku o kontroli niektórych inwestycji ${ }^{31}$ i ustawę z dnia 16 grudnia 2016 roku o zasadach zarządzania mieniem państwowym ${ }^{32}$. Trzeba jednak zaznaczyć, że tylko ta pierwsza normuje postępowanie w sposób odpowiadający modelowi postępowania administracyjnego.

\section{A. PROCEDURY WYKORZYSTUJĄCE MODEL POSTĘPOWANIA UNORMOWANEGO W K.P.A.}

Przedstawiając interesujące nas tu kwestie w pewnym uproszczeniu, można stwierdzić, że ustawa o kontroli niektórych inwestycji normuje tryb kontroli inwestycji skutkujących nabyciem lub osiągnięciem istotnego uczestnictwa albo nabyciem dominacji nad spółkami objętymi ochroną wskazanej ustawy (art. 1 pkt 1). Jak wynika z jej przepisów, objęte ochroną tej ustawy są spółki z udziałem Skarbu Państwa działające w strategicznych branżach gospodarki, w tym wytwarzania energii elektrycznej, przesyłania paliw gazowych, produkcji renu (art. 4 ust. 1).

29 Choć postępowania takie, a zwłaszcza wydawane w ich ramach decyzje, mają wpływ na sytuację przedsiębiorcy — na ich status prawny, majątkowy, pozycję na rynku itp.

30 To jest przed nabyciem takiej liczby akcji w spółce z udziałem Skarbu Państwa, która pozwoli na wybór większości członków rady nadzorczej i powołanie zarządu kontrolowanego przez nowego akcjonariusza; zob. M. Mataczyński, Komentarz do art. 1, [w:] Ustawa o kontroli niektórych inwestycji. Komentarz, red. M. Mataczyński, Warszawa 2016, s. 13-15.

31 Dz.U. z 2016 r. poz. 980 ze zm. (dalej: ustawa o kontroli niektórych inwestycji).

32 Dz.U. z 2016 r. poz. 2259 ze zm. (dalej: ustawa o zasadach zarządzania mieniem państwowym). 
Ich wykaz określa Rada Ministrów w drodze rozporządzenia ${ }^{33}$. Procedurę kontroli wszczyna zgłoszenie (zainteresowanego nabyciem, o którym mowa w art. 1 pkt 1) zawiadomienia o zamiarze dokonania transakcji, z załączonymi dokumentami wskazanymi w ustawie (art. 5-6). Czynność, o której mowa w zawiadomieniu, może być dokonana pod warunkiem braku zgłoszenia sprzeciwu (art. 9 ust. 9). Organ kontroli, to jest minister właściwy do spraw energii bądź Prezes Rady Ministrów (art. 3 pkt 6), zgłasza sprzeciw, gdy (poza przyczynami braków formalnych) jest to uzasadnione takimi względami, jak strzeżenie niepodległości i nienaruszalności terytorium RP, zapewnienie porządku publicznego albo bezpieczeństwa RP (art. 11 ust. 1); zgodnie z założeniami polityki państwa w dziedzinach życia społecznego lub gospodarczego. Ustawa zastrzega, że podstawą sprzeciwu organu kontroli nie może być interes ekonomiczny państwa (art. 11 ust. 4). Sprzeciw wydawany jest w formie decyzji administracyjnej (art. 9 ust. 5-6) ${ }^{34}$ — do postępowań prowadzonych na podstawie ustawy w zakresie nią nieuregulowanym stosuje się przepisy k.p.a. (art. 11 ust. 5), a ochrona sądowa należy do sądu administracyjnego (art. 9 ust. 4 i 6 ).

Konstrukcja prawna sprzeciwu jest jednoznaczna zarówno co do przesłanek i celu podjęcia przez organ administracji, jak i formy prawnej oraz środków ochrony sądowej. Istotę sprzeciwu stanowi władcza ingerencja organu administracji publicznej w określoną transakcję pomiędzy podmiotami objętymi swobodą kontraktowania (art. $353^{1}$ k.c. $)^{35}$. Ingerencja ta determinowana jest stypizowanymi zagrożeniami związanymi ze zmianą, na skutek planowanej transakcji, statusu spółek objętych ochroną na mocy wskazanej ustawy. Zapobieżenie tym zagrożeniom stanowi interes publiczny wymagający ochrony. Sprzeciw, ze względu na formę prawną decyzji i procedurę jej podjęcia, ma charakter administracyjnoprawny i objęty jest kontrolą sądowoadministracyjną ${ }^{36}$.

Podobny model relacji między administracją publiczną a przedsiębiorcami realizuje ustawa z dnia 18 marca 2010 roku o szczególnych uprawnieniach ministra właściwego do spraw energii oraz ich wykonywaniu w niektórych spółkach kapi-

33 Kryteria objęcia wykazem to między innymi istotny udział danego podmiotu w rynku oraz „rzeczywiste i wystarczająco poważne zagrożenie dla fundamentalnych interesów społeczeństwa” (art. 4 ust. 2 ustawy o kontroli niektórych inwestycji).

34 Pomijam w tych rozważaniach kwestie roli komitetu konsultacyjnego w procesie kontroli, uprawnionego do przedstawienia „rekomendacji” w zakresie zasadności wydania decyzji (zob. art. 10 ustawy o kontroli niektórych inwestycji).

35 Ustawa z dnia 23 kwietnia 1964 r. - Kodeks cywilny (tekst jedn. Dz.U. z 2017 r. poz. 459 ze zm.; dalej: k.c.). Szerzej zob. M. Mataczyński, E. Kochańska, Komentarz do art. 11, [w:] Ustawa o kontroli..., s. 158-163.

$36 \mathrm{~W}$ doktrynie prawa spółek wskazuje się, że konstrukcja sprzeciwu zawarta w przepisach komentowanej ustawy może być oceniana z punktu widzenia uznania mechanizmu za formę ,złotej akcji”. Sprzeciw jest bowiem uprawnieniem władczym państwa dającym mu nieproporcjonalne do zaangażowania kapitałowego uprawnienia i możliwości wpływania na działalność spółki. Zob. M. Mataczyński, E. Kochańska, op. cit., s. 163. 
tałowych lub grupach kapitałowych prowadzących działalność w sektorach energii elektrycznej, ropy naftowej oraz paliw gazowych ${ }^{37}$. Unormowany przepisami tej ustawy mechanizm kontroli transakcji dotyczących określonych składników mienia służy ochronie „infrastruktury krytycznej”, będącej w posiadaniu określonych spółek kapitałowych, środkiem zaś interwencji właściwego organu, to jest organu właściwego do spraw energii elektrycznej, jest „sprzeciw” wyrażany w formie decyzji administracyjnej ${ }^{38}$.

Przedstawione rozwiązania prawne obu ustaw jednoznacznie sytuują kompetencje ministra do spraw energii elektrycznej (a także Prezesa Rady Ministrów — w świetle ustawy o kontroli inwestycji) w sferze imperium ${ }^{39}$.

\section{B. PROCEDURA UNORMOWANA PRZEPISAMI USTAWY O ZASADACH} ZARZĄDZANIA MIENIEM PAŃSTWOWYM. PROBLEMY KLASYFIKACYJNE

Tak jednoznacznej kategoryzacji, jaką udało się przeprowadzić odnośnie do wskazanych wcześniej ustaw, nie poddają się konstrukcje unormowane przepisami ustawy o zasadach zarządzania mieniem państwowym, obejmujące między innymi nadzór nad czynnościami prawnymi państwowych osób prawnych (rozdz. 7). We wskazanym zakresie regulują one postępowanie w sprawie wniosku państwowej osoby prawnej, w tym przedsiębiorstwa państwowego (art. 3 ust. 1 pkt 15), o wyrażenie ,zgody” na rozporządzanie mieniem powyżej określonej wartości (art. 38 ust. 1-2). Organami właściwymi w sprawie wyrażenia zgody są (w zależności od wartości przedmiotu transakcji) Prezes Prokuratorii Generalnej oraz organ nadzorujący państwową osobę prawną. W wypadku przedsiębiorstwa państwowego organem nadzorującym jest organ założycielski, czyli naczelny bądź centralny organ administracji państwowej ${ }^{40}$.

Przepisy ustawy szczegółowo normują treść wniosku o wyrażenie zgody, w tym wskazanie uzasadnienia gospodarczego czynności prawnej (art. 39 ust. 1 pkt 5); dokumenty, które należy załączyć; możliwość uzupełnienia wniosku i dokumentacji oraz terminy rozpatrzenia wniosku. Nie określają jednak formy praw-

37 Tekst jedn. Dz.U. z 2016 r. poz. 2012 r. ze zm. (dalej: ustawa o szczególnych uprawnieniach ministra właściwego do spraw energii).

38 Organ może wyrazić „sprzeciw”, gdy przedmiotem podjętej przez zarząd spółki uchwały lub czynności prawnej dokonanej przez zarząd spółki jest rozporządzenie składnikami mienia wchodzącego w skład „,infrastruktury krytycznej”, stanowiące rzeczywiste zagrożenie dla funkcjonowania, ciągłości działania oraz integralności infrastruktury krytycznej. W sprawach nieuregulowanych do postępowania w sprawie „sprzeciwu” stosuje się przepisy k.p.a., a kontrolę sądową sprawuje sąd administracyjny.

39 Tak też podaje I. Postuła w odniesieniu do regulacji ustawy o szczególnych uprawnieniach ministra właściwego do spraw energii; zob. idem, Wielość ról Ministra Skarbu Państwa wobec spółek Skarbu Państwa, [w:] I. Postuła, Nadzór korporacyjny w spółkach Skarbu Państwa, Warszawa 2013, s. 204-216.

40 Zob. przepisy ustawy z dnia 25 września $1981 \mathrm{r}$. o przedsiębiorstwach państwowych (tekst jedn. Dz.U. z 2013 r. poz. 1384 ze zm.), zwł. art. 7 ust. 1 pkt 1. 
nej ,zgody”, nie odsyłają do k.p.a. i nie przewidują środka zaskarżenia. Jedyną konsekwencją, jaką ustawa przewiduje w związku z naruszeniem bądź obejściem obowiązku uzyskania zgody, jest orzeczenie o nieważności czynności ${ }^{41}$.

Z pewnością między organem realizującym ustawowe uprawnienie do wyrażenia zgody na umowne rozporządzanie mieniem określonej wartości a państwową osobą prawną ubiegającą się o zgodę nie ma relacji właścicielskich w rozumieniu art. $44^{1} \S 1$ k.c. ${ }^{42} \mathrm{Z}$ kolei przesłanka realizacji ustawowego uprawnienia organu jest tak ogólnikowo określona (uzasadnienia gospodarcze czynności prawnej), że może stanowić kryterium zarówno interesu publicznego, jak i subiektywnego interesu państwowej osoby prawnej. W tym stanie rzeczy do interpretacji konstrukcji zgody organu na rozporządzenie mieniem przez państwową osobę prawną, unormowanej $\mathrm{w}$ omawianej ustawie, niezbędne jest sięgnięcie do regulacji art. $44^{1} \S 2$ k.c. $^{43}$ Przepis ten wskazuje na szczególną pozycję Skarbu Państwa względem innych państwowych osób prawnych. Z mocy ustaw szczególnych Skarb Państwa może bowiem mieć określone uprawnienia majątkowe, które ograniczą prawo własności innych państwowych osób prawnych - i taki przypadek przewidują przepisy ustawy o zasadach zarządzania mieniem państwowym, wyrażając w formie aktu „zgody” swoiste powiązanie władczych działań państwa z jego rolą właścicielską wyrażoną w konstrukcji Skarbu Państwa ${ }^{44}$.

Można dodać, że podobne rozwiązania w omawianym tu zakresie przewidywała ustawa $\mathrm{z}$ dnia 8 sierpnia 1996 roku o zasadach wykonywania uprawnień przysługujących Skarbowi Państwa ${ }^{45}$ i że na tle jej unormowań nie wypracowano jednoznacznego stanowiska co do charakteru prawnego zgody i roli Ministra Skarbu Państwa ${ }^{46}$.

41 W sprawie orzeczenia o nieważności czynności właściwym jest sąd powszechny.

$42 \mathrm{~W}$ myśl art. $44^{1} \S 1$ k.c. „,[w]łasność i inne prawa majątkowe, stanowiące mienie państwowe, przysługują Skarbowi Państwa albo innym państwowym osobom prawnym”. Takie sformułowanie oznacza, że w rozumieniu prawa cywilnego każda państwowa osoba prawna jest właścicielem posiadanego mienia, zarówno przydzielonego w chwili swojego powstania (na przykład przydzielenie mienia tworzonemu przedsiębiorstwu państwowemu albo państwowej uczelni wyższej), jak i nabywanego w trakcie funkcjonowania (na przykład z zysków przedsiębiorstwa). Zob. m.in. W.J. Katner, Komentarz do art. $44^{1}$ Kodeksu cywilnego, [w:] Kodeks cywilny. Komentarz. Czesść ogólna, red. M. Pyziak-Szafnicka, Warszawa 2014, s. 509-512.

43 „Uprawnienia majątkowe Skarbu Państwa względem państwowych osób prawnych określają odrębne przepisy, w szczególności regulujące ich ustrój”.

44 Por. Z. Radwański, Glosa do uchwaty SN z dnia 26 marca 2002 r., III CZP 15/02, OSP 2003, nr 2, poz. 18, teza 1 .

45 Tekst jedn. Dz.U. z 2016 r. poz. 154 ze zm. Została uchylona na podstawie ustawy z dnia 16 grudnia $2016 \mathrm{r}$. - Przepisy wprowadzające ustawę o zasadach zarządzania mieniem państwowym (Dz.U. z 2016 r. poz. 2260).

46 Zob. postanowienie Sądu Apelacyjnego w Warszawie - I Wydział Cywilny z dnia 9 grudnia 2010 r., I ACa 494/10, LEX nr 1120139; oraz uchwała Sądu Najwyższego z dnia 28 października 2010 r., III CZP 73/10, OSNC 2011, nr 3, poz. 28. 


\section{SWOISTOŚĆ PROCEDUR PUBLICZNEGO PRAWA GOSPODARCZEGO}

Jak wynika z prowadzonych rozważań, stosowane w sferze gospodarki procedury normujące relacje między administracją publiczną a przedsiębiorcami są bardzo różne. Część z nich opiera się na modelu postępowania jurysdykcyjnego, unormowanym przepisami kodeksu postępowania administracyjnego (pkt 3); z reguły ta podstawowa konstrukcja modyfikowana jest uregulowaniami zmieniającymi lub uzupełniającymi regulację kodeksu.

Na specjalną uwagę zasługują postępowania (pkt 4), których podstawową funkcją jest realizacja określonych interesów (celów) publicznych, takich jak ochrona mienia państwowego lub inwestycji (obiektów) mających znaczenie dla gospodarki, bezpieczeństwa obywateli, porządku publicznego itp. Należy podkreślić, że procedury te nie stanowią jednolitej kategorii — relacje między podmiotem administracji publicznej a przedsiębiorcą normowane są tu w różny sposób.

Przepisy ustawy o kontroli niektórych inwestycji i ustawy o szczególnych uprawnieniach ministra właściwego do spraw energii (pkt 4a) dotyczące przedsiębiorców niepublicznych normują stronę proceduralną relacji z właściwym organem, korzystając z konstrukcji typowych dla postępowania jurysdykcyjnego, w tym z formy rozstrzygnięcia, jaką jest decyzja, a także z ochrony sądowoadministracyjnej i w zakresie nieuregulowanym w danej ustawie odsyłają do k.p.a. Nie jest to jednak postępowanie jurysdykcyjne ${ }^{47}$ — jego przedmiotem jest kontrola określonych czynności prywatnoprawnych, a stanowiący formę władczej ingerenci sprzeciw służy ograniczeniu autonomii woli samodzielnych podmiotów działalności gospodarczej (swobody kontraktowania) w celach realizacji interesów publicznych (celów politycznych). Szczególna funkcja występująca w działaniu organu i stosunki, w które organ wchodzi z podmiotami zewnętrznymi, pozwalają mówić o specjalnym reżimie proceduralnym w ramach ogólnej koncepcji postępowania administracyjnego ${ }^{48}$

Unormowanie nadzoru nad czynnościami prawnymi państwowych osób prawnych, na czele z aktem „zgody” na rozporządzanie mieniem powyżej określonej wartości, bez określenia prawnej formy tego środka i bez wskazania na możliwość zaskarżenia nie mieści się w modelu k.p.a. Pozostaje wobec tego określenie tego trybu postępowania jako szczególny dla relacji podmiotów władzy, w tym administracji publicznej, z państwowymi osobami prawnymi model postępowania, w ramach którego akt „zgody” stanowi wyraz swoistego powiązania władczych działań państwa z jego rolą właścicielską, mającego swe źródło w normie zawartej w art. $44^{1} \S 2$ k.c.

47 Por. B. Adamiak, op. cit., s. 7.

48 Zob. J. Borkowski, A. Krawczyk, Prawo procesowe ogólne..., s. 98-99; por. charakterystykę postępowania podatkowego: iidem, Przedmiot regulacji prawa..., s. 146. 
Uwzględniając powyższe, należy zwrócić uwagę na konsekwencje obowiązywania różnych procedur określających publicznoprawne relacje między administracją publiczną a przedsiębiorcami, a zwłaszcza takich procedur, których podstawową funkcją nie jest kształtowanie pozycji prawnej przedsiębiorcy i przesłanką wchodzenia $\mathrm{w}$ relacje zewnętrzne $\mathrm{z}$ przedsiębiorcami jest realizacja określonych celów (interesów) gospodarki. Takie cele postępowania nie są zbieżne z założeniami konstrukcyjnymi postępowania ogólnego unormowanego w k.p.a., co wywołuje problem gwarancji procesowych dla przedsiębiorców.

\section{PODSUMOWANIE. KWESTIA OCHRONY PRAW PRZEDSIĘBIORCÓW (GWARANCJI PROCESOWYCH)}

Jak zaznaczono na wstępie artykułu, zagadnienie to może być w tym opracowaniu jedynie zarysowane. Podstawę refleksji w tym zakresie stanowić będą podstawowe tezy doktryny prawa procesowego administracyjnego.

Należy się zgodzić ze stanowiskiem, że powszechne postępowanie administracyjne kreuje najdalej idące gwarancje procesowe dla strony w toku załatwiania indywidualnej sprawy administracyjnej przez organ administracji publicznej, co znajduje wyraz przede wszystkim w zasadach ogólnych k.p.a. ${ }^{49}$ Zasady te odnoszą się do ogólnego postępowania administracyjnego i obowiązują w nim w pełnym zakresie $^{50}$. Zasady ogólne stosuje się także w postępowaniach odrębnie unormowanych, jeżeli przepisy regulujące te postępowania odsyłają do k.p.a. Należy przypomnieć, że takie odesłania mają miejsce w postępowaniach omówionych w punkcie 4a niniejszego opracowania.

Powszechnie akceptowany jest również pogląd, że zasady ogólne k.p.a., a przynajmniej ich znaczna część, powinny być realizowane przez organy administracji publicznej w każdej ich działalności, również poza postępowaniem administracyjnym zmierzającym do wydania decyzji ${ }^{51}$. Przypomnieć należy, że w postępowaniach omówionych w punkcie 4a właściwą formą prawną wydawanego przez organ sprzeciwu jest decyzja administracyjna, choć nie stanowi ona rozstrzygnięcia indywidualnej sprawy administracyjnej. Z racji odmiennej — od trybu jurysdykcyjnego - funkcji wskazanych postępowań oczywisty wydaje się wniosek, że nie wszystkie zasady ogólne k.p.a. mogą znaleźć w nich zastosowanie. Uwaga ta tym bardziej dotyczy postępowania przedstawionego w punkcie $4 \mathrm{~b}$, które w żadnym aspekcie nie nawiązuje do modelu postępowania unormowanego w k.p.a. Ujawnia się zatem problem adekwatności gwarancji procesowych

49 Z. Kmieciak, Postepowanie administracyjne w świetle standardów europejskich, Warszawa 1997, s. 296; B. Adamiak, J. Borkowski, Kodeks postepowania administracyjnego. Komentarz, Warszawa 2000, s. VI.

50 Z. Janowicz, Kodeks postępowania administracyjnego. Komentarz, Warszawa 1995, s. 52.

51 Zob. J. Zimmermann, op. cit., s. 171. 
unormowanych w k.p.a. do niektórych postępowań uregulowanych przepisami publicznego prawa gospodarczego.

Przykładem zasady ogólnej k.p.a., której ratio legis nie jest spójne z podstawowym celem omówionych w punktach $4 \mathrm{a}-\mathrm{b}$ postępowań, jakim jest ochrona interesu publicznego, jest zasada uwzględniania interesu społecznego i słusznego interesu strony (art. 7 k.p.a.). Wydaje się, że nie zmienia tego stanu rzeczy także ostatnia nowelizacji k.p.a. ${ }^{52}$, która uzupełnia katalog zasad ogólnych dotyczących postępowania administracyjnego między innymi o zasadę rozstrzygania na korzyść strony wątpliwości dotyczących treści normy prawnej, występujących przy wydawaniu decyzji zobowiązujących (art. 7a $§ 1$ k.p.a.) ${ }^{53}$, łącznie z zastrzeżeniem, że przepisu tego nie stosuje się, jeżeli wymaga tego ważny interes publiczny, w tym istotne interesy państwa, a w szczególności jego bezpieczeństwa, obronności lub porządku publicznego (art. 7a $\S 2$ k.p.a.).

W tym kontekście nasuwa się pytanie o rolę zasad ogólnych normowanych przepisami publicznego prawa gospodarczego: w jakim zakresie przepisy te modyfikują (a może „tylko" powtarzają) zasady ogólne unormowane w k.p.a., a zwłaszcza czy formułują własne zasady postępowania w relacjach organ administracjiprzedsiębiorca, w tym stanowiące gwarancje procesowe adekwatne do warunków działania przedsiębiorców, ale i uwzględniających zadania organów administracji publicznej, podporządkowane określonym celom (interesom) publicznym? W doktrynie publicznego prawa gospodarczego do tego zagadnienia przywiązuje się coraz większą wagę ${ }^{54}$, uwzględniając nie tylko obowiązującą USDG, lecz także projekt ustawy Prawo przedsiębiorców (dalej: Projekt). Zarówno USDG, jak i wskazany Projekt normują bowiem zasady ogólne postępowania ${ }^{55}$. Nadto Projekt

52 Na marginesie warto podkreślić, że nowela do k.p.a. z 2017 r. została opracowana z inicjatywy ministra właściwego do spraw gospodarki. W doktrynie wskazuje się wręcz na „gospodarcze” ukierunkowanie dokonywanych zmian, w tym dotyczących uproszczenia i przyspieszenia postępowania administracyjnego; zob. J. Zimmermann, op. cit., s. 3-24. Analiza rozwiązań prawnych noweli do k.p.a., choćby we wskazanym zakresie, wykracza jednak poza ramy tego opracowania. W kwestii oceny rozwiązań prawnych noweli do k.p.a. zob. J. Zimmermann, op. cit.; W. Piątek, Kodeks postępowania administracyjnego w świetle ustawy nowelizującej z dnia 7 kwietnia 2017 r. —ogólna charakterystyka zmian, „Zeszyty Naukowe Sądownictwa Administracyjnego” 2017, z. 5, zwł. s. 23-28; w odniesieniu do projektu noweli do k.p.a. zob. Z. Kmieciak, Dylematy reformy prawa ..., s. 3-17.

53 Postępowania, o których mowa w pkt 4, nie służą bowiem do wydawania decyzji zobowiązujących.

$54 \mathrm{Z}$ ostatnich prac zob. B. Popowska, Prawo działalności gospodarczej wobec wymogów dobrej administracji, [w:] Prawo administracyjne wobec współczesnych wyzwań. Księga jubileuszowa dedykowana Profesorowi Markowi Wierzbowskiemu, red. J. Jagielski, D. Kijowski, M. Grzywacz, Warszawa 2018, s. 175-182; a także M. Strzelbicki, Zasada sprawiedliwości proceduralnej w procedurach publicznego prawa gospodarczego, [w:] Swoistość procedur..., s. 57-78.

55 Wyjaśniam rozumienie tego pojęcia, piszę o znaczeniu zasad ogólnych oraz omawiam najważniejsze z zasad, w publikacji Prawo działalności gospodarczej ..., zob. zwłaszcza Wnioski, s. 182. 
w odrębnym rozdziale określa dyrektywy działania organów władzy publicznej 56 „w sprawach z zakresu działalności gospodarczej” (rozdz. 3).

Udzielenie odpowiedzi na niektóre z postawionych pytań nie jest jednak proste i nie polega wyłącznie na analizie odnośnych przepisów. W pierwszej kolejności należy bowiem ustalić, jaki jest zakres obowiązywania USDG i ustawy Prawo przedsiębiorców według wersji Projektu. Zarówno USDG, jak i Projekt regulują bowiem ,podejmowanie, wykonywanie i zakończenie działalności gospodarczej na terytorium Rzeczypospolitej Polskiej” oraz ,zadania organów w tym zakresie”57. Upraszczając, można uznać, że przy wąskiej interpretacji zakresu obowiązywania USDG i Projektu unormowane w każdym z aktów reguły postępowania organów nie będą dotyczyły postępowań omówionych w punktach $4 \mathrm{a}-\mathrm{b}$, ponieważ nie dotyczą one stricte działalności gospodarczej ${ }^{58}$. Jednakże USDG tak określa niektóre z zasad, na przykład ,udzielania pomocy publicznej” (art. 7) i ,wspierania rozwoju przedsiębiorczości" (art. 8), że nadaje im rangę zasad ogólnych publicznego prawa gospodarczego. Projekt takich zasad nie zawiera, co może świadczyć o odmiennej koncepcji ustawy Prawo przedsiębiorców.

Biorąc pod uwagę zaprezentowane wątpliwości wobec rozpoczętej w Sejmie procedury legislacyjnej dotyczącej Projektu i ze względu na ramy opracowania, ze szczegółowymi ustaleniami dotyczącymi znaczenia zasad ogólnych w ustawie Prawo przedsiębiorców, dla omówionych w tym opracowaniu postępowań, należy poczekać do uchwalenia ustawy ${ }^{59}$ i poświęcić temu zagadnieniu odrębne opracowanie. Wtedy też będzie można ocenić, czy (ewentualnie w jakim zakresie) określone w nowej ustawie gwarancje procesowe (w ramach zasad ogólnych lub w rozdziale o ,załatwianiu spraw w zakresie działalności gospodarczej”) uwzględniają specyfikę postępowań uregulowanych przepisami publicznego prawa gospodarczego.

\section{NEW PROCEDURES OF PUBLIC ECONOMIC LAW. THE PROBLEM OF PROCEDURAL GUARANTEES FOR BUSINESS ENTITIES}

\section{Summary}

The basic subject of research within the article are new procedures, regulated by the provisions of public economic law, and the main purpose of the article is to determine their legal nature, with reference to the general administrative procedure. The procedures used in the sphere

56 Definicję zawiera art. 7 pkt 4 Projektu.

57 Projekt w art. 1, określającym zakres obowiązywania, wymienia także ,,prawa i obowiązki przedsiębiorców".

58 We wcześniejszych rozważaniach na s. 597-600 tego opracowania wskazywałam na szczególne cele omawianych postępowań.

59 Ustawa Prawo przedsiębiorców została uchwalona dnia 6 marca 2018 r.; opublikowana dnia 30 marca 2018 r. (Dz.U. poz. 646) i weszła w życie dnia 30 kwietnia 2018 r. 
of the economy that regulate relations between public administration and entrepreneurs are very different. Some of them are based on the model of jurisdictional proceedings, regulated by the provisions of the Code of Administrative Procedure. There should also be distinguished proceedings whose main function is the implementation of specific public interests - these proceedings do not constitute a uniform category, and the relations between the public administration entity and the entrepreneur are regulated in different ways.

Keywords: public economic law, procedures, procedural guarantees

\section{BIBLIOGRAFIA}

Adamiak B., Koncepcja postępowania administracyjnego, [w:] System Prawa Administracyjnego, t. 9. Prawo procesowe administracyjne, red. R. Hauser, Z. Niewiadomski, Warszawa 2014.

Adamiak B., Borkowski J., Kodeks postępowania administracyjnego. Komentarz, Warszawa 2000.

Borkowski J., Krawczyk A., Aspekt przedmiotowy regulacji prawa procesowego administracyjnego, [w:] System Prawa Administracyjnego, t. 9. Prawo procesowe administracyjne, red. R. Hauser, Z. Niewiadomski, Warszawa 2014.

Borkowski J., Krawczyk A., Prawo procesowe ogólne, prawo procesowe szczególne, [w:] System Prawa Administracyjnego, t. 9. Prawo procesowe administracyjne, red. R. Hauser, Z. Niewiadomski, Warszawa 2014.

Borkowski J., Krawczyk A., Przedmiot regulacji prawa procesowego administracyjnego. Rodzaje spraw i ich charakter prawny: sprawa indywidualna bez ograniczenia przedmiotowego, sprawa podatkowa jako rodzaj sprawy administracyjnej, [w:] System Prawa Administracyjnego, t. 9. Prawo procesowe administracyjne, red. R. Hauser, Z. Niewiadomski, Warszawa 2014.

Funkcje współczesnej administracji gospodarczej, red. B. Popowska, Poznań 2006.

Instrumenty i formy prawne działania administracji gospodarczej, red. B. Popowska, K. Kokocińska, Poznań 2009.

Janowicz Z., Kodeks postepowania administracyjnego. Komentarz, Warszawa 1995.

Katner W.J., Komentarz do art. $44^{1}$ Kodeksu cywilnego, [w:] Kodeks cywilny. Komentarz. Część ogólna, red. M. Pyziak-Szafnicka, Warszawa 2014.

Kiczka K., O niektórych aspektach procedur w publicznym prawie gospodarczym, [w:] Swoistość procedur publicznego prawa gospodarczego, red. B. Popowska, Poznań 2013.

Kiczka K., Prawo administracyjne gospodarcze w systemie prawa administracyjnego, [w:] Koncepcja systemu prawa administracyjnego, red. J. Zimmermann, Warszawa 2007.

Kieres L., Sprawna administracja w orzecznictwie Trybunału Konstytucyjnego, [w:] Administracja publiczna pod rzadami prawa. Księga pamiątkowa z okazji 70-lecia urodzin prof. zw. dra hab. Adama Błasia, red. J. Korczak, Wrocław 2016.

Kmieciak Z., Dylematy reformy prawa o postępowaniu administracyjnym, „Państwo i Prawo” 2016, z. 1.

Kmieciak Z., Postępowanie administracyjne w świetle standardów europejskich, Warszawa 1997.

Kmieciak Z., Postepowanie w sprawach ochrony konkurencji a koncepcja procedury hybrydowej, „Państwo i Prawo” 2002, z. 8.

Kosikowski C., Polskie publiczne prawo gospodarcze, Warszawa 2000.

Kosikowski C., Publiczne prawo gospodarcze Polski i Unii Europejskiej, Warszawa 2007.

Mataczyński M., Komentarz do art. 1, [w:] Ustawa o kontroli niektórych inwestycji. Komentarz, red. M. Mataczyński, Warszawa 2016.

Mataczyński M., Kochańska E., Komentarz do art. 11, [w:] Ustawa o kontroli niektórych inwestycji. Komentarz, red. M. Mataczyński, Warszawa 2016. 
Piątek W., Kodeks postępowania administracyjnego w świetle ustawy nowelizującej z dnia 7 kwietnia 2017 r. - ogólna charakterystyka zmian, ,Zeszyty Naukowe Sądownictwa Administracyjnego" 2017, z. 5.

Popowska B., Klasyfikacja funkcji administracji w nauce publicznego prawa gospodarczego, [w:] Funkcje współczesnej administracji gospodarczej, red. B. Popowska, Poznań 2006.

Popowska B., Kwalifikacja prawna umowy koncesji: instrument ,mieszany” czy typowy dla realizacji zadań gospodarczych przez administrację publiczna?, [w:] Prawne instrumenty oddziatywania na gospodarke, red. A. Powałowski, Warszawa 2016.

Popowska B., Partnerstwo publiczno-prywatne w świetle koncepcji ,ciagu działań prawnych” $i$ jej wplyw na ocene umowy o PPP, [w:] Środki prawne publicznego prawa gospodarczego, red. L. Kieres, Wrocław 2007.

Popowska B., Prawo działalności gospodarczej wobec wymogów dobrej administracji, [w:] Prawo administracyjne wobec współczesnych wyzwań. Księga jubileuszowa dedykowana Profesorowi Markowi Wierzbowskiemu, red. J. Jagielski, D. Kijowski, M. Grzywacz, Warszawa 2018.

Popowska B., Publiczne prawo gospodarczej w płaszczyźnie proceduralnej, [w:] Nowe problemy badawcze w teorii publicznego prawa gospodarczego (z uwzględnieniem samorzadu terytorialnego), red. L. Kieres, Wrocław 2010.

Postuła I., Nadzór korporacyjny w spótkach Skarbu Państwa, Warszawa 2013.

Rabska T., Jakie prawo gospodarcze? — próba odpowiedzi, „Ruch Prawniczy, Ekonomiczny i Socjologiczny" 1993, nr 1.

Radwański Z., Glosa do uchwaty SN z dnia 26 marca 2002 r., III CZP 15/02, OSP 2003, nr 2, poz. 18.

Strzelbicki M., Zasada sprawiedliwości proceduralnej w procedurach publicznego prawa gospodarczego, [w:] Swoistość procedur publicznego prawa gospodarczego, red. B. Popowska, Poznań 2013.

Strzyczkowski K., Uwagi o zadaniach nauki o prawnych formach działania administracji gospodarczej, [w:] Instrumenty i formy prawne działania administracji gospodarczej, red. B. Popowska, K. Kokocińska, Poznań 2009.

Swoistość procedur publicznego prawa gospodarczego, red. B. Popowska, Poznań 2013.

Środki prawne publicznego prawa gospodarczego, red. L. Kieres, Wrocław 2007.

Zimmermann J., Kilka refleksji o nowelizacji kodeksu postępowania administracyjnego, „Państwo i Prawo" 2017, z. 8. 